\title{
Crónicas de Cuzcatlán-Nequepio y del Mar del Sur
}

Editorial Lis, San Salvador, 2011; 314 páginas

Autor: Pedro Antonio Escalante Arce

Es un libro de historia escrito en parámetros tradicionales, con profusión de datos e investigación en fondos documentales y bibliográficos de España, México, Guatemala, Nicaragua y El Salvador, así como en Washington D.C. y su Biblioteca del Congreso. Es una compilación de estudios y comentarios sobre diferentes aspectos de la historia colonial de las provincias salvadoreñas y del Reino de Guatemala en general, algunos de los cuales ya el autor había tratado en obras anteriores. En las Crónicas de Cuzcatlán-Nequepio y del Mar del Sur se pone el acento en temas relacionados con el siglo XVI, con la presentación de aspectos históricos que no habían recibido la importancia que revisten, o no mencionados por los historiadores. Se trata de un panorama que en mucho es novedoso y desborda en su temática la ruta tradicional trazada por los antecesores salvadoreños en esta materia.

El mismo nombre Nequepio suscita alguna extrañeza para quienes han visto el título de la obra. No se trata más que del nombre con que se conocía la parte de Cuzcatlán desde el sur centroamericano, desde Panamá y Nicaragua. Hay varias descripciones geográficas que hacen coincidir ese nombre con el Cuzcatlán nahua-pipil, además del uso común que se hizo de él en León de Nicaragua. Se le ha dado la explicación etimológica de "tierra extraña".

El descubrimiento de las costas del actual El Salvador, por la expedición de Andrés Niño y Gil González Dávila en 1522-1523, había sido reseñada muy superficialmente, sin un estudio pormenorizado de su integración, circunstancias y alcances geográficos. Sin embargo, su interés está más allá de las usuales breves menciones, con mucha documentación que refleja los preparativos, la integración y los resultados contradichos por algunos contemporáneos, incluso por el cronista que más se refirió a esta navegación, considerada un viaje menor dentro de los de descubrimiento, como es Gonzalo Fernández de Oviedo. 
El viaje de Andrés Niño involucra la presencia trascendente del controvertido Pedrarias Dávila, que quiso entorpecer la expedición de Niño y González Dávila por una no disimulada envidia por las capitulaciones que habían firmado con la Corona. Pedrarias Dávila, primero gobernador de Panamá y luego de Nicaragua, por otro lado, con los ímpetus dirigidos hacia el norte del istmo, siempre pretendió hacer valer los derechos que creía tener sobre la región salvadoreña translempina oriental y aun sobre la margen derecha occidental, cislempina, del río. Sobre este tema hay incidentes que tal vez pueden considerarse para Pedrarias como generador de derechos de conquista y de jurisdicción geográfica sobre el presente El Salvador, aun en una época de desconocimiento en cuanto a la verdadera conformación de estas tierras. Tal es el acuerdo que Pedrarias, ya gobernador de Nicaragua, formalizó con el gobernador de Honduras, Diego López de Salcedo, en enero de 1529, cuyo resultado inmediato fue la invasión del oriente, hoy salvadoreño, entonces llamado genéricamente Popocatépet "cerro que humea" por lo españoles de Nicaragua, y su llegada, a finales de ese año, de la tropa al mando de Martín Estete, hasta la recién establecida villa de San Salvador, en 1528, sobre la cual también reclamaba derechos.

Estos aducidos derechos sobre San Salvador en Ciudad Vieja tienen un antecedente hasta ahora prácticamente ignorado en la historia colonial salvadoreña. Se trata de la llegada de Hernando de Soto a la "gran ciudad de Nequepio", o sea, la población de Cuzcatlán, a finales de 1524, o en los primeros días de 1525, lo que está plasmado en la carta de Pedrarias Dávila a Carlos V de mayo de 1525, desde Panamá. Nunca se le dio interés por los historiadores nacionales porque erróneamente situaron Nequepio como otro nombre de la Choluteca hondureña. La llegada de Hernando de Soto a la población de Cuzcatlán es la explicación de la fundación apresurada del primer San Salvador a principios de 1525 , con solamente un ayuntamiento compuesto por la tropa enviada, un cabildo organizado en el real, en el campamento, sin ninguna pretensión inmediata de poblamiento ni urbanismo, porque lo indispensable era marcar jurisdicción de conquista para Pedro de Alvarado, ante la ya manifiesta avanzada por el sur en nombre de Dávila.

El libro también refiere la prisa por establecer la villa de San Miguel de la Frontera en el Popocatépet oriental, en 1530, para señalar demarcación próxima con Nicaragua; de ahí su indicación fronteriza. Una población primero asentada en las cercanías del indígena Usulután, y a corta distancia de la bahía del Espíritu Santo, o Jiquilisco, donde Alvarado usará, más adelante, el astillero 
de Xiriualtique. Una aportación de las Crónicas son los datos sobre el comercio esclavista desatado después de la refundación de San Miguel, en 1535, con barcos que llegaban a cargar indígenas al golfo de Fonseca para llevarlos como esclavos al sur.

Capítulo especial merece, en el libro, el frustrado viaje de Alvarado a las islas Molucas, expedición que partió de Acajutla a principios de septiembre de 1540 y terminó en México, por los arreglos con el virrey Antonio de Mendoza de organizar nuevos destinos. Uno de ellas sería, ya muerto Alvarado en julio de 1541, la de Juan Rodríguez Cabrillo, enviada por Mendoza, que descubrió la Alta California a finales de 1542, donde se emplearon barcos de Alvarado, al igual como se habrá utilizado más de alguno proveniente de la armada de Acajutla en el descubrimiento de las islas Filipinas por Ruy López de Villalobos.

El Fonseca ocupa una parte principal y protagónica en el libro, junto con otros varios temas náuticos, con un ambiente oceánico que le confiere a las Crónicas un carácter particular, centrado en el Mar del Sur y las navegaciones. Y por primera vez un libro de historia relata ampliamente el surgimiento de la Amapala histórica, la que se encontraba en la parte hoy salvadoreña, muy distinta de la Amapala hondureña, o sea el puerto en la isla del Tigre organizado a mediados del siglo XIX por el italiano, residente en San Miguel, Carlos Dárdano, por cuenta del gobierno de Tegucigalpa, quien llevó el nombre Amapala hasta la parte insular de Honduras. Amapala era en la Alcaldía Mayor de San Salvador, un asentamiento precolombino que se convirtió en lugar de embarque utilizado para dirigirse hacia Nicaragua, un uso que ya habrá tenido en la época precolombina. Quien le dio carta de ciudadanía a Amapala fue Pedro de Alvarado, al organizar allí su flota para la expedición hacia el Perú, reconcentrada frente a la caleta del sitio en el año 1533. Desde Amapala salían españoles con indígenas auxiliares a combatir indígenas rebeldes que se hacían fuertes en peñoles y amenazaban a la débil y novata villa de San Miguel, establecida en las proximidades del pueblo indígena de Usulután.

En 1590 se creó la guardianía franciscana de Santa María de las Nieves en Amapala, y el convento se levantó en 1593 en el lugar hoy conocido como Pueblo Viejo, sitio arqueológico depredado que marca el emplazamiento del convento seráfico, destruido por bucaneros franceses al mando de un capitán Grogniet en 1686. Santa María de las Nieves tuvo a su cargo 
la atención religiosa de los habitantes de las islas Meanguera y Conchagua, también llamada isla de Amapala, hasta que los isleños vieron sus pueblos incendiados por filibusteros ingleses en 1684, por lo que un grupo de ellos fundó el nuevo Santiago de Conchagua en tierra firme, al pie del volcán de Amapala, hoy volcán de Conchagua.

A Amapala había llegado, en 1590, el grupo de ingenieros enviados por la Corona para evaluar la posibilidad de la ruta transístmica Fonseca-Puerto Caballos, expertos encabezados por el célebre Juan Bautista Antonelli. El proyecto no tuvo realización por lo caro de adecuar los caminos, poblar la ruta y cuidar ambas bahías, además del trabajo que iba a significar el cambio de destino final de la flota de Tierra Firme, que se pretendía recogiera los envíos de plata peruana en el norte de Honduras, cargamento argentífero que se recibiría en un nuevo puerto construido en el golfo, el puerto de Fonseca, trazado y urbanizado a orillas de la desembocadura del río Sirama (estero La Manzanilla), donde llegarían los galeones desde El Callao.

Varios capítulos del libro están dedicados a los viajes de celebrados corsarios y piratas, y su aparecimiento en las costas salvadoreñas. Como el de Francis Drake, que llegó en 1579, el de Thomas Cavendish en 1587, los de William Dampier en 1684 y los inicios de 1705, y otros. Estas expediciones depredadoras tuvieron mucha importancia en cuanto al mejor conocimiento de las costas y de las corrientes marinas. En el actual El Salvador la piratería del Mar del Sur tuvo su gran época a finales del siglo XVII. Un testimonio de esa racha pirática son las dos imágenes de Nuestra Señora de las Nieves que todavía existen, provenientes del desaparecido convento de Amapala. Una de ellas, medio quemada por el incendio que arrasó la casa franciscana, se encuentra en la histórica parroquia de Santiago Conchagua. La otra fue llevada a San Miguel, y se modificó la escultura piadosa en su talla original; hoy está entronizada en la catedral como Nuestra Señora de la Paz, patrona de El Salvador.

Las Crónicas de Cuzcatlán-Nequepio y del Mar del Sur han sido el fruto de un buen esfuerzo y de mucha investigación por varios años. Una obra muy particular en su género, que viene a enriquecer la literatura histórica sobre los siglos de la monarquía española en las provincias salvadoreñas. 


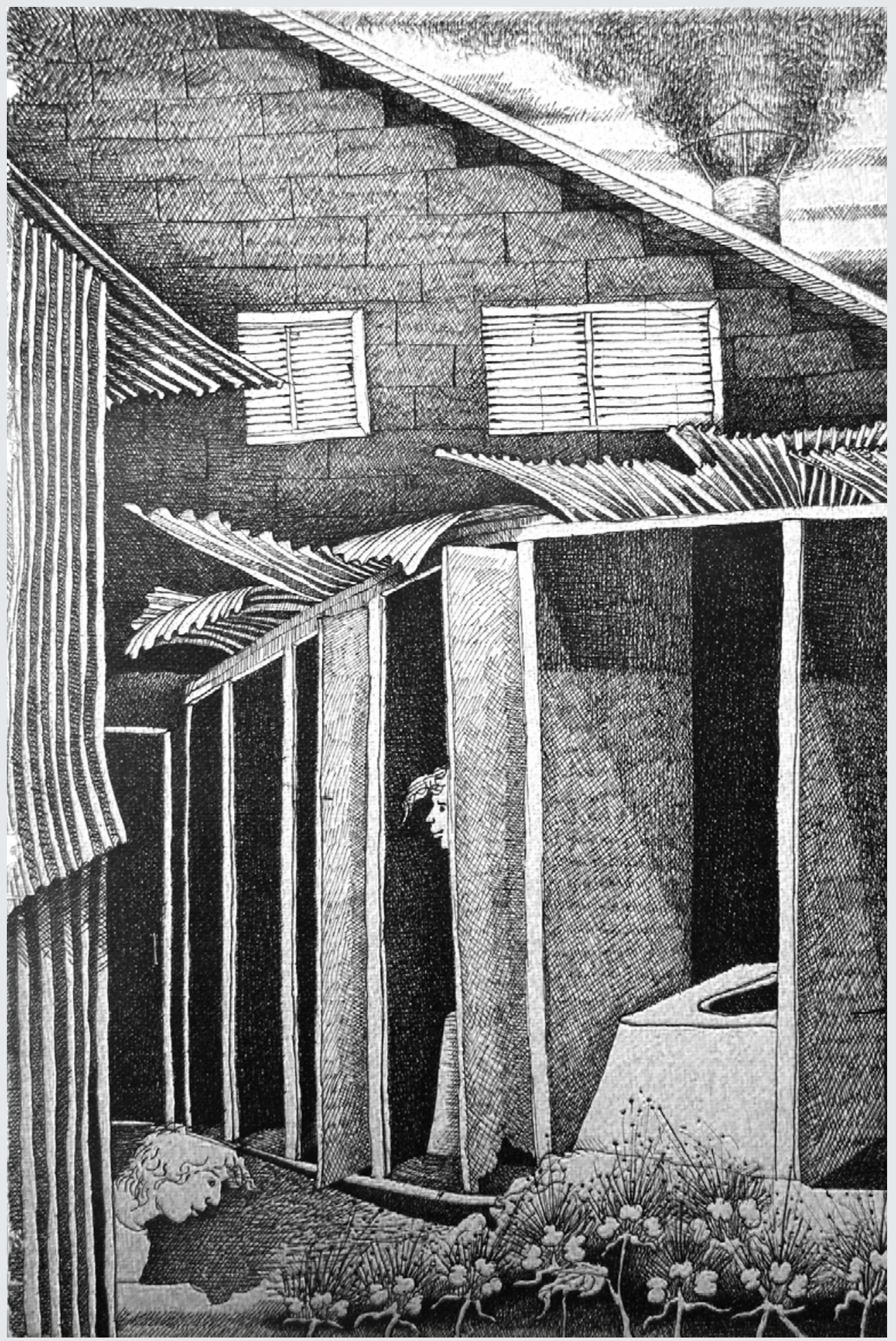

